\title{
The pigment complex and photosynthetic activity in the annual cycle of Polytrichum commune in the forest belt of the Khibiny Mountains on the Kola Peninsula of Russia
}

\author{
Natalya Shmakova*, Olga Ermolaeva \\ N. A. Avrorin Polar-Alpine Botanical Garden-Institute, Kola Science Centre Russian \\ Academy of Sciences, Fersman street 18a, Apatity, Murmansk region, 184209, Russia
}

\begin{abstract}
This paper presents data on the content and ratio of pigments, photosynthesis rate, and assimilation number throughout the annual cycle of Polytrichum commune in the forest belt of the Khibiny Mountains. It is shown that the activity of the pigment complex in the photosynthetic organs of $P$. commune is preserved and maintained over 2 years. The highest content of plastid pigments in this year's shoots was recorded in fall, in the past year's shoots in the summer. In winter, the content of chlorophylls in the photosynthetic organs of this year's shoots decreased in 1.5 times relative to the summer maximum, and carotenoids - in 1.4 times. In the past year's shoots, no significant changes in the content of the pigments were noted. During the active vegetation period, the photosynthetic intensity in this year's shoots is in 1.5 times as high as that in the past year's shoots. At the end of the growing season in the past year's shoots the value of LHC (76\%) due to their immersion deep into the moss clumps and shading them with this year's shoots. Chlorophyll's efficiency (assimilation number) in $P$. commune shoots of different ages in early spring (April) is in 2 times as high as that in fall (October).
\end{abstract}

Key words: moss, this year's and the past year's shoots, annual cycle, chlorophylls, carotenoids, apparent photosynthesis, assimilation number

DOI: $10.5817 / C P R 2020-1-4$

\section{Introduction}

Plant productivity in the Far North remains a relevant area of research in connection with global climate change and the need to forecast future changes in the vegetation patterns at high latitudes (Longton 1992, Martin and Adamson 2001), where bryophyte play a leading role. Mosses are found everywhere up to the Arctic desert, and are dominants and co-dominants in many plant communities. In the Khibiny Mountains, mosses are an important component of the forest vegetation and play a significant role in the accumulation of organic matter and in the biological nutrient cycles of the ecosystems (Pereverzev 2012). Because of their unique physiology and morphology, mosses have an effective system of regulating water regime and are

Received August 21, 2019, accepted January 10, 2020.

*Corresponding author: N. Shmakova <shmanatalya@yandex.ru> 
thus highly tolerant to environmental factors, allowing them to colonize habitats where spermatophytes are unable to succeed. Photosynthetic organs of mosses, similarly to those of evergreen plants, maintain their pigment complex active over a long time, extending the period of photosynthetic activity during the short growing season in the Far North (Lukyanova et al. 1986, Yatsco et al. 2009).

Bryophytes generally have chlorophyll concentrations typical of shade-loving plants (Tieszen and Johnson 1968). The total chlorophyll content in bryophytes varies in a wide range depending on habitat from 0.67 to $11.56 \mathrm{mg} \mathrm{g}^{-1}$ of dry weight (Martin 1980, Masarovičova and Elias 1987, Doera and Chaudhary 1991). A study of 39 species of mosses and 16 species of liverworts showed that the average chlorophyll content in mosses is $1.64 \mathrm{mg} \mathrm{g}^{-1}$ of dry weight and $3.76 \mathrm{mg} \mathrm{g}^{-1}$ of dry weight in liverworts; the chlorophyll $(a / b)$ ratio was 2.29 and 1.99 , respectively; the ratio of chlorophylls and carotenoids was 4.74 in mosses and 6.75 in liverworts (Marschall and Proctor 2004). The chlorophyll $(a / b)$ ratio falls due to an increase in the proportion of chlorophyll $b$, which is typical for plants adapted to growing in shade. Most bryophytes have developed physiological adaptations to low light intensities, have low chlorophyll $(a / b)$ ratios, which may vary significantly (1.0-2.5) depending on the availability of light, season, and degree of adaptation (Mishler and Oliver 1991). Bryophytes are capable of adapting

\section{Material and Methods}

\section{Study site}

The study was carried out in the protected area of the Polar Alpine Botanical Garden-Institute (PABGI) in the forest belt of the Khibiny Mountains $\left(67^{\circ} 34^{\prime} \mathrm{N}, 33^{\circ}\right.$ $36^{\prime} \mathrm{E}$ ). The physiological patterns (growing season and winter period) of plant shoots to low intensity of light by increasing the number of chloroplasts, which was shown for Funaria hygrometrica (Glime 2007). The total pigment content in forest mosses (Kansas, US) increases from early spring (1.45 $\mathrm{mg} \mathrm{g}^{-1}$ of dry weight) to canopy closure $\left(4.36 \mathrm{mg} \mathrm{g}^{-1}\right.$ of dry weight), which is indicative of the indicator's wide range (Martin and Churchill 1982). In forest mosses in Slovakia, a narrower range of 2.14-2.85 mg g $\mathrm{mg}^{-1}$ of dry weight was observed in July (Masarovičová and Elias 1987). In habitats where light is blocked by the snow cover for more than 6 months, a decreased level of chlorophyll is characteristic. In the Antarctic, bryophytes reduce both the content and the chlorophyll $(a / b)$ ratio of during winter (Melick and Seppelt 1994). In some of the most common moss species of the Khibiny Mountains forest belt, a chlorophyll content range of $0.87-4.35 \mathrm{mg} \mathrm{g}^{-1}$ of dry weight was found (Lukyanova et al. 2011). However, few studies exist on the annual dynamics of the photosynthetic activity of mosses in the Far North. Pigment content and ratio have been traditionally used by many researchers to detect the response of plants to changes in their environment (Tuthilkina 2009).

This paper examines the content of photosynthetic pigments and the photosynthetic activity of different ages shoots of Polytrichum commune in the annual cycle the Khibiny Mountains on Russia's Kola Peninsula. of different ages were studied. Patterns during the winter period were studied in a model experiment. Due to the fact that the snow cover in the forest belt can be up to $2 \mathrm{~m}$ deep, which complicates sampling, mono-species moss turfs of $P$. commune 
sized $50 \times 50 \mathrm{~cm}$ were removed in fall and placed in close proximity to the study area (open, flat area above the lab's porch). In this connection, the snow cover depth in the actual forest belt in the PABGI and on the experimental plot may differ (no more than $80 \mathrm{~cm}$ ). On the experimental plot, the snow cover was completely lost 3 weeks earlier than in the forest belt (Fig. 1).

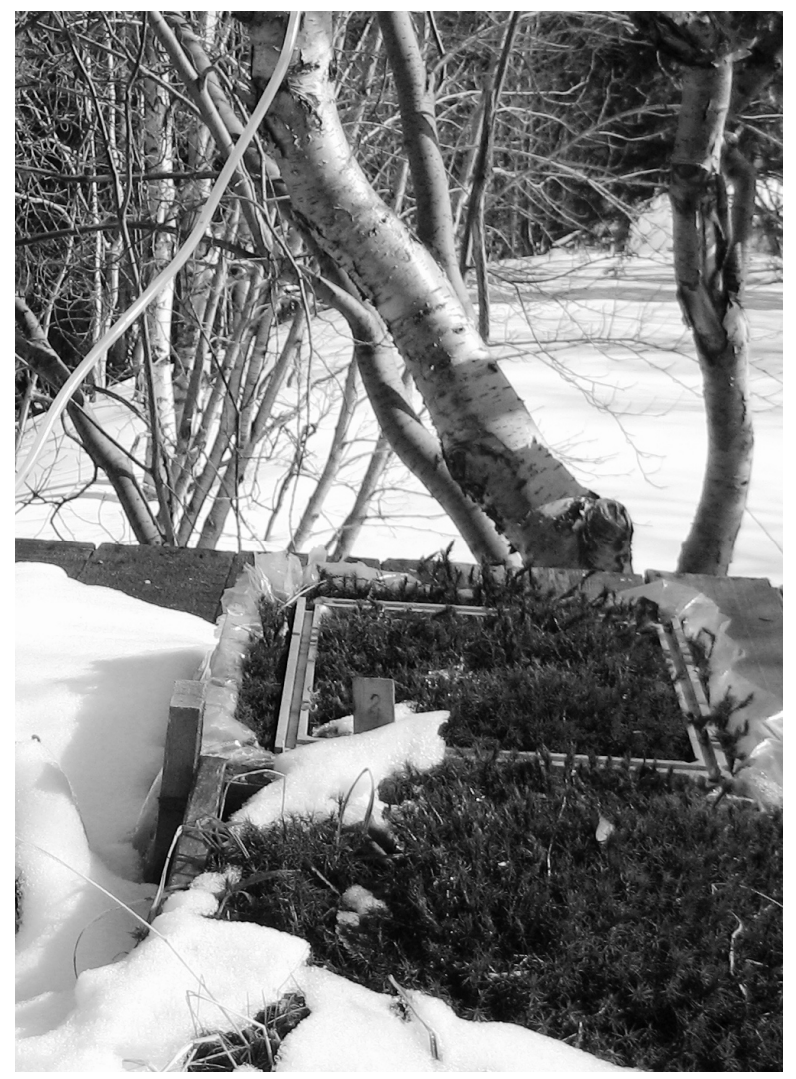

Fig. 1. The turfs of $P$. commune in model experiment (in late April).

\section{Weather data for the study period}

According to the available long-term observation data (from 2009 to 2018), the snow cover was lost between May 21 and June 12. The active growing season begins when the air temperature becomes above $+10^{\circ} \mathrm{C}$ and, as a rule, lasts from early in the second decade of June to the second decade of September. First snow and night frosts often come at the end of September. On average, the vegetation season is 121 days long. Air temperature and snow depth in the forest belt of the Khibiny Mountains during the study period are shown in Fig. 2. During the study period (2011-2013), the establishment of seasonal snow cover was observed in late October, maximum snow depth (170-180 cm) in March, and complete loss of snow cover by late May. Winter air temperatures below $-15^{\circ} \mathrm{C}$ were infrequent. Maximum daily average air temperatures during the growing season did not exceed $+19^{\circ} \mathrm{C}$. 


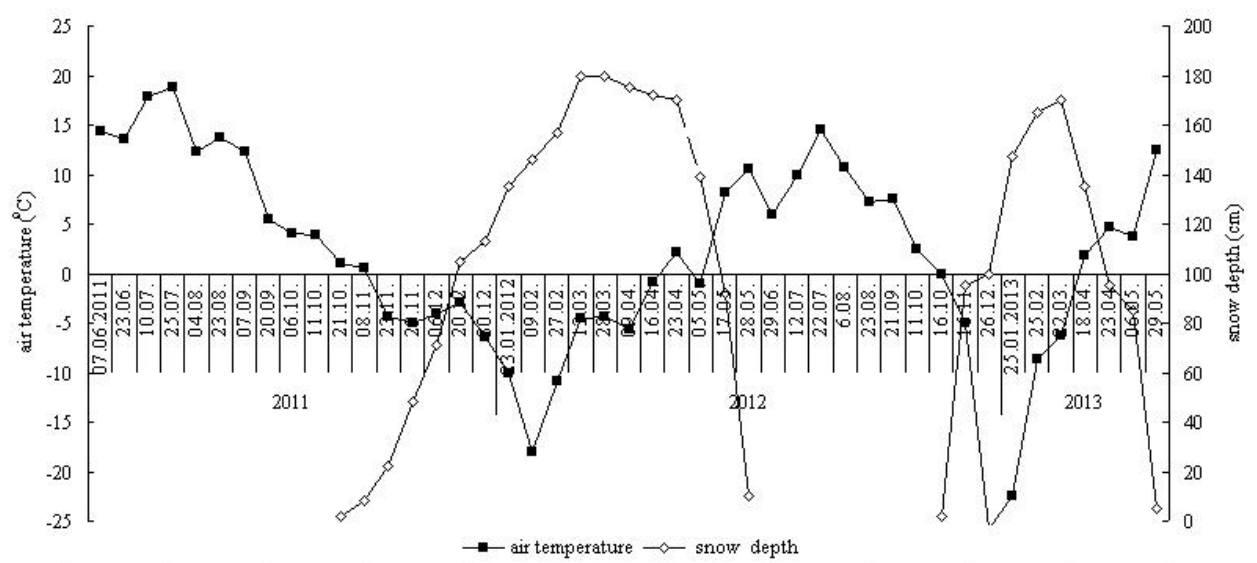

Fig. 2. Air temperature and snow cover height in the period June 2011 to June 2013 at the Khibiny forest belt (PABGI).

Study subject

Polytrichum commune Hedw. belongs to the Polytrichaceae family, is one of the largest acrocarpous moss species, and forms loose or thick dark green turfs. In the forest communities of the Khibiny Mountains, $P$. commune is a dominant or codominant species; in some habitats, it forms microgroups with a cover of $80-100 \%$. Gametophyte annual shoots are clearly identified by the bend of the stem; in the climatic conditions prevalent in the Khibiny Mountains, shoots of the past two years are

\section{Study methods}

The water content in fresh moss was measured by drying to an absolutely dry weight at $105^{\circ} \mathrm{C}$. The content of photosynthetic pigments (chlorophylls - Chl $a$ and Chl $b$ and carotenoids - Car) was measured in ethanol extracts spectrophotometrically (Lichtenthaler and Wellburn 1983) with an UV-1800 (Shimadzu, Japan) at corresponding absorption maxima (Chl $a-$ at $665 \mathrm{~nm}$, Chl $b$ - at $649 \mathrm{~nm}$, and Car - at $470 \mathrm{~nm})$. The proportion of chlorophylls in the light-harvesting complex (LHC, \%) of photosynthetically active (green).

$P$. commune, being an endohydric species, is capable of retaining moisture in its tissues for a long time and is thus resistant to moisture loss. Average water content in $P$. commune tissues is $60-63 \%$. During prolonged periods with no precipitation, the water content in $P$. commune tissues never falls below 40\% (Ermolaeva and Shmakova 2017). In this study, shoots were classified into this year's and the past year's shoots.

their total was calculated by assuming that all Chl $b$ is held in the LHC and that the $\mathrm{Chl}(a / b)$ ratio in the LHC is 1.2 (Lichtenthaler 1987). Net (apparent) photosynthesis was measured using open-flow infrared gas analysis system (GAMMA-100, Russia). To quantify the relationship between the content of chlorophylls and the rate of photosynthesis, the assimilation number $\left(\mathrm{A}_{\mathrm{n}}\right)$ in $\mathrm{mg}$ of $\mathrm{CO}_{2}$ per hour per $1 \mathrm{mg}$ of chlorophyll was calculated (Andrianova and Tarchevsky 2000). The annual cycle of 
photosynthetic pigments was studied from 2011 to $2013 ; \mathrm{CO}_{2}$ gas exchange was measured from 2009 to 2018 during the growing seasons (from June to October). In April-May, data were collected in a model experiment. During this period, mosses were extracted from under the snow for analysis. Productivity parameters (length and mass of the annual shoots) were measured during the growing season from 2009 to 2018 every 7-10 days (at least 50 replicate measurements). Physiological varia- bles (water content, plastid pigments content and gas exchange rate) were measured on the day of sampling; the number of replications of the experiments was twice the biological frequency.

Air temperature measurements ( 1 meter above the moss turfs) were taken daily using iBDLR-3-UX loggers at the established weather observation times. Statistical processing of the data was done in Statistica 10 .

\section{Results and Discussion}

\section{The content of photosynthetic pigments in shoots of different ages}

In the forest belt, in $P$. commune individuals emerging from under the snow, new shoots (1-2 $\mathrm{mm})$ are immediately noticeable. This suggests that the growth starts under the snow, when its depth is not more than $20 \mathrm{~cm}$. Light can penetrate throughh a snow layer that thick, and favorable greenhouse-like temperature conditions can develop (Tikhomirov 1952, Zyuzin 2006). Three weeks after the complete melting of the snow cover, shoots were about $6 \mathrm{~mm}$ long, which was $15 \%$ of the maximum annual shoots length at the end of the growing season (on average, $39 \mathrm{~mm}$ ). In late June, when snowmelt runoff terminates, dry periods combined with

This year's shoots (Fig. 3. The period from 08.06.2011 to 28.05.2012): At the end of the first decade of June, the total content of plastid pigments in the photosynthetic organs of this year's shoots was the lowest and amounted to $1.8 \mathrm{mg} \mathrm{g}^{-1}$ of dry weight for chlorophylls and $0.4 \mathrm{mg} \mathrm{g}^{-1}$ of dry weight for carotenoids (Fig. 3 A). In the first decade of July, when the highest growth rate in $P$. commune was observed, the content of green and yellow pigments increased in 1.5 times relative in June. In low temperatures often occur, which inhibits the growth of mosses. Maximum daily average growth rate in $P$. commune becomes possible when an effective temperature sum (above $+5^{\circ} \mathrm{C}$ ) of approximately $389^{\circ} \mathrm{C}$ has been accumulated, what was noted by a number of studies for other moss species (Bates 1989, Callaghan and Carlsson 1997). In the Khibiny Mountains, this can be observed already in the first decade of July. In late August, the shoots length is $90 \%$, its mass $85 \%$ of the annual values. The growth processes terminate at the end of September, while photosynthetic activity may continue in the presence of favorable conditions.

late August, the chlorophyll content nearly doubles, compared to the beginning of the growing season. The $\mathrm{Chl}(a / b)$ ratio in this year's shoots varies between 2.9 and 3.3, the proportion of chlorophyll in the LHC is $50-63 \%$, the water content in the fresh moss is $60-70 \%$ (Fig. 3 B). The increase of chlorophylls amount is due largely to chlorophyll $a$. The content of carotenoids in this period reaches the maximum of $0.8 \mathrm{mg} \mathrm{g}^{-1}$ of dry weight. 

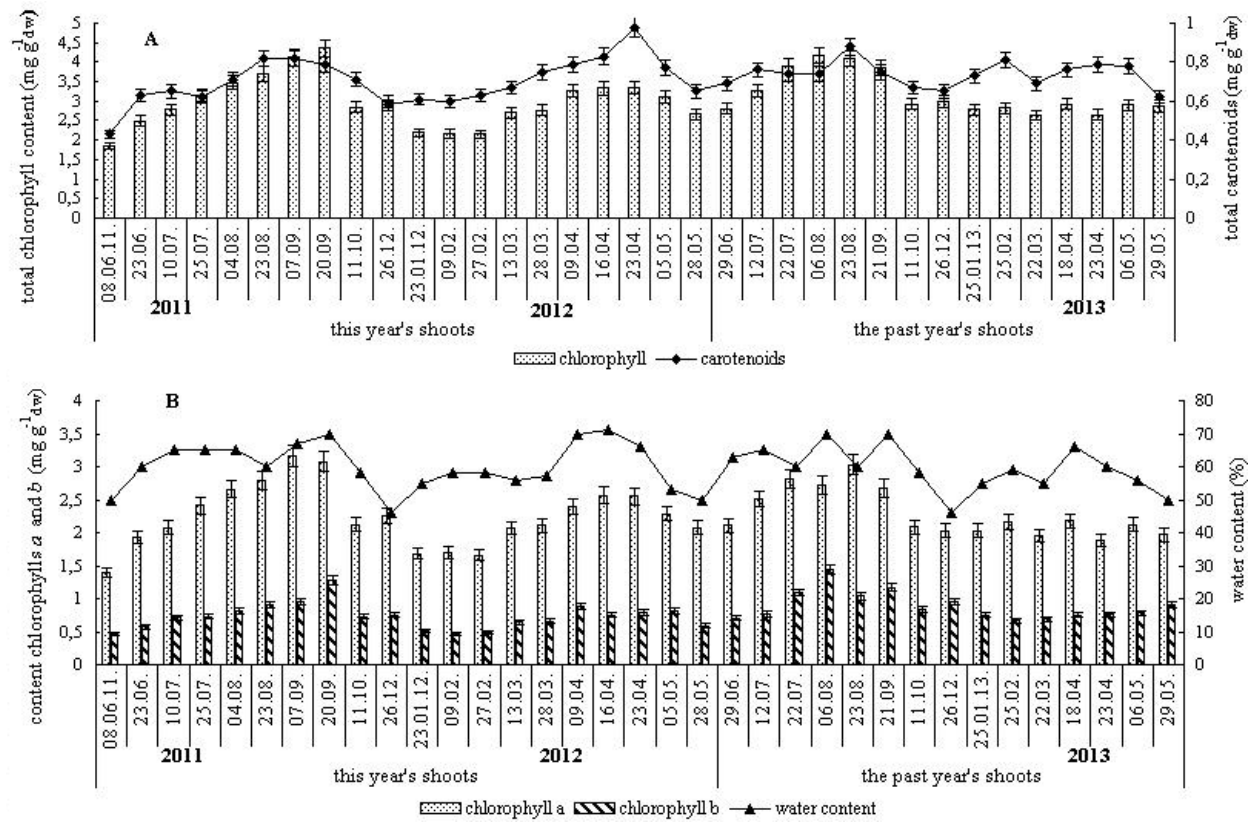

Fig. 3. The photosynthetic pigments content in $P$. commune shoots of different ages in the annual cycle: A - the total content chlorophyll and carotenoids; B - the content of chlorophylls $a$ and $b$ and water content. Note: $\mathrm{dw}-$ dry weigh.

At the end of September, when the formation of the annual shoots is completed (Ermolaeva et al. 2013, Ermolaeva and Shmakova 2017), the content of green pigments reaches its maximum during the growing season (4.4 $\mathrm{mg} \mathrm{g}^{-1}$ of dry weight). The $\mathrm{Chl} /$ Car ratio during the growing season (June-October) is within the range of 4.0 to 5.5 . In this year's shoots in the end of growing season the concentration of chlorophylls and carotenoids increased to 2.4 and 1.9 times as high as beginning season, respectively.

In December, the content of chlorophylls in the photosynthetic organs of this year's shoots decreased in 1.5 times relative to the summer maximum, and carotenoids - in 1.4 times. The water content in the fresh moss is $46 \%$. In JanuaryFebruary, the content of chlorophylls was $2.2 \mathrm{mg} \mathrm{g}^{-1}$ of dry weight and remains stable until early March. The $\mathrm{Chl} / \mathrm{Car}$ ratio during this period was an average of 3.5.
The decrease in the Chl/Car ratio compared to that in the growing season is due to a greater degree of reduction in the content of chlorophylls than carotenoids.

In early March, the relatively stable pigment complex of this year's $P$. commune shoots starts to change. According to the long-term data, in March-April in the Khibiny forest belt, the maximum depth of the snow cover can reach $180-200 \mathrm{~cm}$, while in our model experiment, it did not exceed $120-130 \mathrm{~cm}$. Earlier, we found that with changes in air temperature between 0 and $-27^{\circ} \mathrm{C}$ (January-April), the temperature of the photosynthetic part of the moss turfs under the snow varies between 0 and $-7.5^{\circ} \mathrm{C}$ (Shpak and Shmakova 2009). Bryophyte leaves are more resistant to freezing temperatures than those of flowering plants. Snow gives significant protection against freezing in winter; when it begins to melt, voids becomes filled with snow crystals and light penetration increases. This can be 
a signal for bryophytes to start photosynthesis, growth, and development even before the snow melts (Marchand 1993). Only a small amount of light, especially in the blue and blue-green spectrum, can penetrate through the dense snow layer. In the same period in the Khibiny Mountains, the solar radiation influx increases from 3.7 in March to $8.1 \mathrm{kcal} \mathrm{cm}^{-2}$ in April (Zyuzin 2006). In mid-April, the snow depth above the studied $P$. commune turfs (in the model experiment) did not exceed $30 \mathrm{~cm}$. In March-April, the content of total chlorophylls and carotenoids in this year's shoots in 1.5-1.7 times as high as that the minimum value in winter. The $\mathrm{Chl} / \mathrm{Car}$ ratio varies at this time from 3.4 to 4.1 . Water content is $70 \%$. The increase in the content of carotenoids and the shadow pigment $\mathrm{Chl} b$ in March-April can be considered as a defense reaction to increase the stability of the photosynthetic organs, which contributes to additional light capture and the delivery of additional energy to the reaction centers of Chl a (Czeczuga 1987, Popova et al. 1989, Slemnev et al. 2012). The defense protecting the photosynthetic organs from photo-destruction at low tem-

The past year's shoots (Fig. 3. The period from 29.06.2012 to 29.05.2013): Starting in June (Fig. 3A), when new shoots start to form, this year's shoots are classified as the past year's shoots. In the past year's shoots, the content of chlorophyll in June ( $2.8 \mathrm{mg} \mathrm{g}^{-1}$ of dry weight) is at the same level as after the winter in late May. Maximum concentration of chlorophyll in the past year's shoots ( $4.2 \mathrm{mg} \mathrm{g}^{-1}$ of dry weight) was recorded in August. The Chl $(a / b)$ ratio change from 3.2 in July to 1.9-2.9 in August-September; the chlorophyll content in LHC change from 52 to $76 \%$, respectively. The change in the chlorophyll content in the past year's shoots is mainly due to the concentration of $\mathrm{Chl} b$. This increase is the result of the immersion of the past year's shoots deep into the moss turfs and peratures and under excessive insolation in the early spring is the accumulation of various components of the violaxanthin cycle: for example, zeaxanthin in evergreen woody plants; neoxanthin in some evergreens of the grass-shrub layer (Yatsco et al. 2009). As observed by Tikhomirov (1952) on the Taimyr Peninsula, at the end of the winter period, due to the winter activity of mosses, a layer of granular powdery snow forms between the mosses and the denser snow cover. He believes that mosses might be photosynthetically active as soon as the polar night ends. Under the thermal action of light penetrating through the snow, «snow greenhouses» are formed.

In period, when the snow cover has completely melted away, the water content in fresh moss was $50-53 \%$. Such low content is a protective mechanism against freezing damage by low temperatures and night frosts characteristic of the Khibiny Mountains in May. During the same period, we noted a decrease in the content of chlorophylls (Fig. 3A: 23.04-28.05.2012). Some researchers (Tuzhilkina and Veretennikov 1981) attribute this decrease to the beginning of growth processes.

shading them with this year's shoots. The $\mathrm{Chl} / \mathrm{Car}$ ratio varies in the range of 4.1 to 5.6. The maximum carotenoids content was observed in August $\left(0.9 \mathrm{mg} \mathrm{g}^{-1}\right.$ of dry weight). With the onset of cold weather in fall, the leaves start browning and the total content of green and yellow pigments decreases in 1.4 times relative to the summer maximum. Further, with the onset of the winter period, no major changes were observed in the pigment content in the past year's shoots.

Thus, the highest content of plastid pigments in this year's shoots was in fall and coincided with the end of the annual shoot growth. In the past year's shoots maxima content of plastid pigments was in summer. In winter the amount of pigments in both years' shoots was decreased com- 
pared with summer. In the past year's shoots under the snow cover, no significant changes in the content of chlorophylls were noted. It is shown that the activity of the pigment complex in the photosynthetic organs of $P$. commune is preserved and maintained over the 2-year life cycle. The pigment complex in $P$. commune is characterized by a low content of chlorophylls and carotenoids, which is nevertheless comparable to that in evergreen and wintergreen vascular plants (Lukyanova et al. 1986, Yatsco et al. 2009, Sofronova et al. 2007).

\section{$\mathrm{CO}_{2}$ gas exchange rate in shoots of different ages}

The main growth form in mosses is a gametophyte without pronounced developmental phases; therefore, seasonal gas exchange differs from that of vascular plants in that there are no clear dynamics. Seasonal changes are mainly associated with fluctuations of environmental factors. In the June, when the low air temperatures and no shading, the primary role in the assimilation of carbon dioxide in $P$. commune belongs to the past year's shoots, whose photosynthetic rates are within the range of 2 to $6 \mathrm{mg} \mathrm{CO}_{2}$ g dry weight ${ }^{-1} \mathrm{~h}^{-1}$ (Fig. 4). In the first decade of July, when the maximum growth rate was observed, photosynthetic rates in this year's shoots was higher than in the past year's shoots. During the period of active vegetation (July-August), the primary factor limiting the photosynthetic activity in $P$. commune is water content, rather than air temperature. As the annual shoots forms, the photosynthetic rate gradually increases, reaching the highest values (12 $\mathrm{mg} \mathrm{CO}_{2} \mathrm{~g}$ dry weight ${ }^{-1} \mathrm{~h}^{-1}$ ) in August. In this period, the photosynthetic rate in this year's shoots is in 1.6 times as high as that in the past year's shoots. At the end of August, browning of the foliage can be observed in the past year's shoots. Starting in the third decade of September, when the annual shoots has fully formed (length and mass no longer change), average daily air temperatures are consistently below $+10^{\circ} \mathrm{C}$, water regime no longer plays a decisive role, and the net photosynthesis range becomes narrow- er than in summer. In the second half of October, when, as a rule, the average daily air temperatures is near $0^{\circ} \mathrm{C}$, the photosynthetic rate in this and the past year's shoots does not exceed 1-2 mg $\mathrm{CO}_{2} \mathrm{~g}$ dry weight ${ }^{-1} h^{-1}$.

Growth processes in mosses can start as early as under the snow. The potential level of photosynthesis in $P$. commune shoots extracted from under the snow was investigated in a model experiment. According to our data, the earliest start of photosynthetic activity in this species was observed at the end of March, when the snow depth was $15 \mathrm{~cm}$ and 200 lux of light was transmitted through the snow. The temperature in the chamber was $-3.3^{\circ} \mathrm{C}$, while the ambient temperature ranged from -4.2 to $-1.6^{\circ} \mathrm{C}$. In mid-April, the air temperature is within the range of 0 to $+6^{\circ} \mathrm{C}$ and $P$. commune was photosynthetic activity. The photosynthesis rate in the second half of April can be up to $5 \mathrm{mg} \mathrm{CO}_{2} \mathrm{~g}_{\text {dry weight }}{ }^{-1} \mathrm{~h}^{-1}$ in this year's shoots and up to $4.4 \mathrm{mg} \mathrm{CO}_{2}$ $\mathrm{g}$ dry weight ${ }^{-1} \mathrm{~h}^{-1}$ in the past year's shoots (Fig. 4: 16.04.-12.05.). The water content in fresh moss was in the optimal range (60-68\%). During this period, as a rule, the average daily temperature was above $0^{\circ} \mathrm{C}$. Photosynthetic efficiency in April can be the same as in July, but at a lower air temperature. We found that photosynthetic activity in this year's shoots (overwintered) in April-May is higher than of the past year's shoots. 


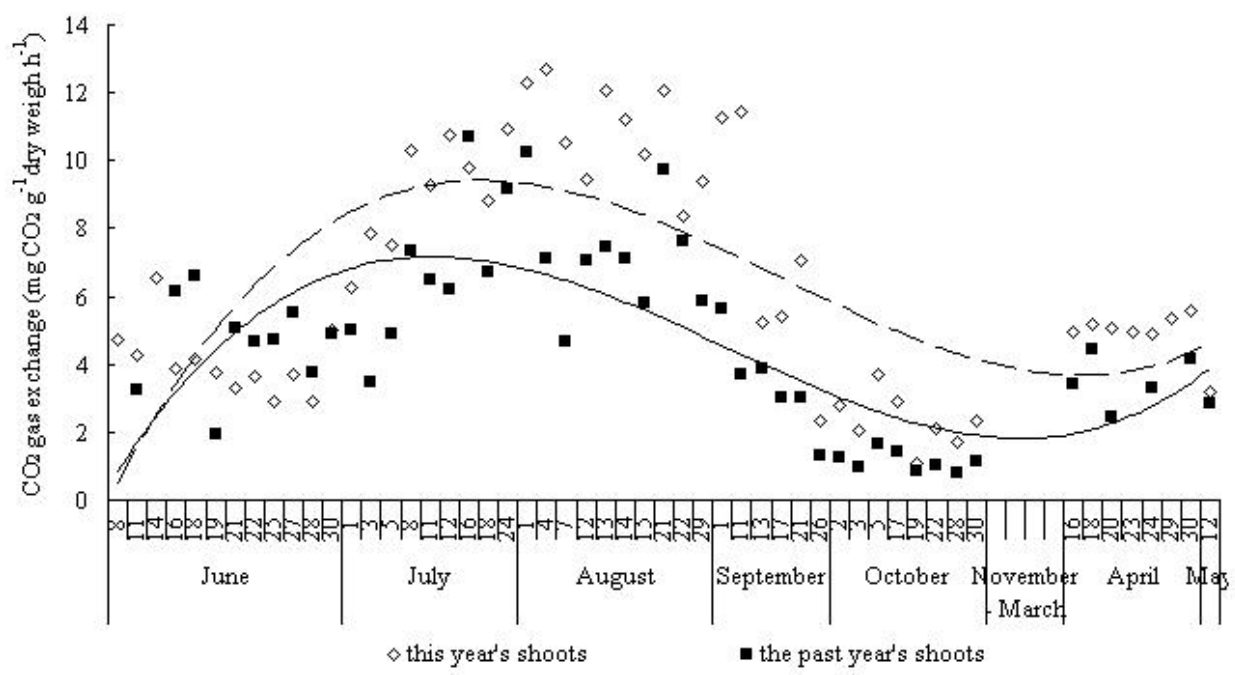

Fig. 4. Seasonal dynamics of $\mathrm{CO}_{2}$ gas exchange in $P$. commune shoots of different ages: this year's shoots - open symbols (dotted line); the past year's shoots - closed symbols (solid line).

Despite the ambiguity of the relationship between the content of chlorophyll in the photosynthetic organs and the rate of $\mathrm{CO}_{2}$ uptake, we found it possible to use the value of the assimilation number $\left(\mathrm{A}_{n}\right)$ as a variable characterizing the photosynthetic rate in different ages shoots of $P$. commune. Using data on the content of chlorophyll and the net gas exchange rate, we estimated the $A_{n}$ of the shoots in different periods of the annual cycle (Table 1). Mosses, being poikilohydric plants, depend on the availability of water and do not have phenological development phases; therefore, $A_{n}$ can be examined depending on the climatic conditions of the seasons of the year in nature. Multiple methods exist for identifying seasonal climatic patterns. For example, in areas with a persistent snow cover, the annual cycle can be conventionally divided into growing season and cold winter season (Kuryina et al. 2013). According to the method proposed in that paper, the beginning of the annual cycle is the date when the average daily air temperature has below $0^{\circ} \mathrm{C}$ and the snow cover has appeared, while the end of the cold season is the date when the snow has melted away. Annual vegetation season is the period from the date when the snow has melted away to the date when the average air temperature was above $+5^{\circ} \mathrm{C}$ (effective temperature), the active vegetation season starts when the average daily temperature was above $+10^{\circ} \mathrm{C}$, and fall starts when the average daily air temperature has dropped below $+10^{\circ} \mathrm{C}$.

In the Khibiny Mountains, the annual cycle begins at the end of October, when the snow cover is usually established and the daily temperature has below $0^{\circ} \mathrm{C}$. During this period, the $A_{n}$ in this year's shoots is in 1.4 times as high as that in the past year's shoots. This is followed by a 5-month long winter period with polar night and deep snow and, accordingly, no photosynthetic activity. April is one of the last months of the cold part of the annual cycle in the Khibiny Mountains; in late April, the climatic conditions initiate snowmelt and mosses resume their photosynthetic activity. This is evidenced by the value of $\mathrm{A}_{\mathrm{n}}$, which in April is in 1.8-2 times as high as that in October, despite the similar tem- 


\begin{tabular}{|c|c|c|}
\hline Annual cycle period & Shoots & $\begin{array}{c}\text { Assimilation number, } \\
\left(\mathrm{A}_{\mathrm{n}}\right) \mathrm{mg} \mathrm{CO}_{2} \\
\text { mg chlorophyll }^{-1} \mathrm{~h}^{-1}\end{array}$ \\
\hline \multirow{2}{*}{$\begin{array}{l}\text { October (daily average air temperature } \\
\text { below } 0^{\circ} \mathrm{C} \text { ) }\end{array}$} & 1 & 1.0 \\
\hline & 2 & 0.7 \\
\hline \multirow{2}{*}{$\begin{array}{l}\text { April (snowmelt, daily average air } \\
\text { temperature around or above } 0^{\circ} \mathrm{C} \text { ) }\end{array}$} & 1 & 1.8 \\
\hline & 2 & 1.4 \\
\hline \multirow{2}{*}{$\begin{array}{l}\text { May (release from snow cover, daily average } \\
\text { air temperature above }+5^{\circ} \mathrm{C} \text { ) }\end{array}$} & 1 & 0.8 \\
\hline & 2 & 0.9 \\
\hline \multirow{2}{*}{$\begin{array}{l}\text { June (daily average air temperature } \\
\text { above }+10^{\circ} \mathrm{C} \text { ) }\end{array}$} & 1 & 1.6 \\
\hline & 2 & 2.5 \\
\hline \multirow{2}{*}{$\begin{array}{l}\text { July } \\
\text { (active vegetation) }\end{array}$} & 1 & 3.1 \\
\hline & 2 & 2.0 \\
\hline \multirow{2}{*}{$\begin{array}{l}\text { August } \\
\text { (active vegetation) }\end{array}$} & 1 & 3.5 \\
\hline & 2 & 2.1 \\
\hline \multirow{2}{*}{$\begin{array}{l}\text { September (growth stops, daily average air } \\
\text { temperature below }+10^{\circ} \mathrm{C} \text { ) }\end{array}$} & 1 & 1.2 \\
\hline & 2 & 1.0 \\
\hline
\end{tabular}

Table 1. Chlorophyll efficiency in Polytrichum commune shoots of different ages. Note: 1 - this year's shoots; 2 - the past year's shoots.

perature conditions. In May, when the snow cover has melted away, air temperatures rise, but the accumulated meltwater quickly evaporates and mosses become limited by water in their photosynthetic activity, which is significantly reduced. The $A_{n}$ is almost the same in shoots of different ages and is comparable in magnitude with the fall values. By the third decade of June, new shoots have formed, but their photosynthetic organs are still not as efficient as those of the past year's shoots, which in the fall and spring were still considered this year's shoots. In this connection, the photosynthetic efficiency of the past year's shoots in June is in 1.6 times as high as that in this year's shoots. July and August are active vegetation periods under the studied conditions, when mosses are char- acterized by high growth rates subject to a favorable combination of temperature and water availability. At this time, the past year's shoots begin to reduce their photosynthetic efficiency and become shaded by this year's shoots, whose photosynthetic activity was in 1.6-1.7 times as high as that the past year's shoots. It was in this period that the highest values of photosynthetic rate and $A_{n}$ was recorded. In September, moss growth terminates and the final stage of the annual vegetation season begins. In fall, the assimilation number decreases in 2.9 (this year's shoots) and in 2.1 (the past year's shoots) times as low as to the maximum. By the beginning of a new annual cycle, the past year's shoots lose photosynthetic activity faster. 


\section{Conclusion}

The photosynthetic apparatus of Polytrichum commune preserves the pigment complex for two years, which can be considered as one of the ways adaptations to growing in a cold climate. The high stability of the photosynthetic apparatus is indicated by the ability of the species to quickly restore and maintain photosynthetic activity after frost and release from snow cover. The ability to preserve the photosynthetic apparatus in winter compensates for the low growth rate. Comparability of main parameters of the photosynthetic apparatus of $P$. commune with that of some deciduous and evergreen undershrub species testifies to the great contribution of this plant group to the productivity of northern ecosystems (Shmakova et al. 1996). As in evergreen vascular plants, a decrease in the content of chlorophyll and an increase in the content of carotenoids were observed in mosses in the autumnwinter period, which contributes to a greater resilience of the photosynthetic apparatus and protects chlorophylls from destruction.

This endohydric species is characterized by a highly flexible pigment complex, allowing to occupy habitats with a broad range of light conditions. The highest photosynthetic activity was observed in JulyAugust, and in this year's shoots it was in 1.5 times as high as that in the past year's ones. An early start of photosynthetic activity was observed in this moss as early as at the end of the cold part of the annual cycle (in April).

\section{References}

Andrianova, Y. E., TARChevsky, I. A. (2000): Chlorophyll and plant productivity. Nauka, Moscow, Russia, 2000, 135 p. (In Russian).

BATES, J. W. (1989): Growth of Leucobryum glaucum cushion in a Berkshire oak wood. Journal of Bryology, 15: 785-791.

Callaghan, T. V., CARlsson, B. A. (1997): Impacts of climate change on demographic processes and population dynamics in Arctic plants. In: W. C. Oechel, T. V. Callaghan, T. Gilmanov, J. I. Holten, B. Maxwell, U. Molau, B. Sveinbjörnsson (eds.): Global Change and Arctic Terrestrial Ecosystems. Springer, New York, pp. 129-152.

Czeczuga, B. (1987): Carotenoids contents in leaves grown under various light intensities. Biochemical Systematics and Ecology, 15: 523-527.

Doera, G. S., Chaudhary, B. L. (1991): Chlorophyll content in some bryophytes. Indian Botanical Contactor, 8: 95-97.

Ermolaeva, O. V., Shmakova, N. Yu. and Lukyanova, L. M. (2013): Of the growth of Polytrichum, Pleurozium and Hylocomium in the forest belt of the Khibiny Mountains. Arctoa, 22: 7-14. (In Russian).

ERmolaeva, O. V., Shmakova, N. Yu. (2017): Growth and mass accumulation of Polytrichum commune in Khibiny mountains forest belt. Scientific notes of Petrozavodsk state University, 6 (167): 38-44. (In Russian).

Guime, J. M. (2007): Light the shade plants. In: Bryophyte Ecology. Chapter 9-1, pp. 5-6. http://www.bryoecol.mtu.edu.

Kuryina, I. V., Philandycheva, L. B., Bokova (Bulatova), U. A., SAPyjan, E. S. and Klimova, N. V. (2013): A study of the climatic seasons and their impact on the living components of wetland ecosystems (on the example of the oligotrophic bogs of the subtaiga subzone of the West Siberian plain). Vestnik of Tomsk state University, 376: 182-191. (In Russian). 
Lichtenthaler, H. K., Wellburn, A. R. (1983): Determination of total carotenoids and chlorophylls a and b of leaf extracts in different solvents. Biochemical Society Transactions, 11 (5): 591-592.

LichtenthaleR, H. K. (1987): Chlorophylls and carotenoids - pigments of photosynthetic biomembranes. Methods in Enzymology, 148: 350-382.

Longton, R. E. (1992): The role of bryophytes and lichens in terrestrial ecosystems. In: J. W. Bates, A. M. Farmer (eds.): Bryophytes and Lichens in a Changing Environment. Clarendon Press, Oxford, pp. 32-76.

Lukyanova, L. M., LokTeva, T. N. and Bulycheva, T. M. (1986): Gas exchange and pigment system of Kola Subarctic plants (Khibiny massif). KFAN USSR, Apatity, Russia, 1986, 127 p. (In Russian).

Lukyanova, L. M., Shmakova, N. Yu. and Ermolaeva, O. V. (2011): Ecologo-physiological studies of plants of the Khibiny. LAP Lambert, Saarbrücken, Deutschland, 121 p. (In Russian).

MARChAND, P. J. (1993): The underside of winter. Natural History, 2: 51-56.

MARTIN, C. E. (1980): Chlorophyll $a / b$ ratios of eleven North Carolina mosses. Bryologist, 83: 8487.

Martin, C. E., Adamson, V. J. (2001): Photosynthetic capacity of mosses relative to vascular plants. Journal of Bryology, 23: 319-323.

Martin, C. E., ChURChill, S. P. (1982): Chlorophyll concentrations and $a / b$ ratios in mosses collected from exposed and shaded habitats in Kansas. Journal of Bryology, 12: 297-304.

Marschall, M., Proctor, M. C. (2004): Are bryophytes shade plants? Photosynthetic light responses and proportions of chlorophyll $a$, chlorophyll $b$ and total carotenoids. Annals of Botany, 94: 593-603.

MASAROVIČOVÁ, E., EliÁs, P. (1987): Some ecophysiological features in woodland mosses in SW Slovakia 2. Chlorophyll content and photosynthesis. Symposia Biologica Hungarica, 35: 113123.

Melick, D. R., Seppelt, R. D. (1994): Seasonal investigations of soluble carbohydrates and pigment levels in Antarctic bryophytes and lichens. Bryologist, 97: 13-19.

Mishler, B. D., Oliver, M. J. (1991): Gametophytic phenology of Tortula ruralis, a desiccationtolerant moss, in the Organ Mountains of southern New Mexico. Bryologist, 94: 143.

Pereverzev, V. N. (2012): Soils of the coasts of fjords of the Western Spitsbergen Island. Kola Science Center, Apatity, Russia, 2012, 121 p. (In Russian).

Popova, I. A., Maslova, T. G. and Popova, O. F. (1989): Features of the pigment apparatus of plants of different botanical and geographical zones. In: O. A. Semihatova (eds.): Ecological and physiological studies of plant photosynthesis and respiration. Nauka, Leningrad, Russia, pp. 115-139. (In Russian).

Shmakova, N. Ju., Lukjanova, L. M., Bulycheva, T. M. and Kudrjavtseva, O. V. (1996): The production process in the mountain tundra communities of Khibiny. Kola Science Center, Apatity, Russia, 125 p. (In Russian).

Shpak, O. V., Shmakova, N. Ju. (2009): The temperature in the moss curtain under the snow cover in the Khibiny mountains. In: Physico-chemical mechanisms of plant adaptation to anthropogenic pollution in conditions of the far North: Doc. Annual meeting of the Society of Plant Physiologists of Russia, Apatity, Russia, pp. 370-371. (In Russian).

Slemnev, N. N., Sheremet'ev, S. N., Maslova, T. G., Zoog, S. and Almansoor, A. (2012): Diversity of photosynthetic apparatus of plants of Mongolia: analysis of biological, ecological and evolutionary series. Botanicheskii Zhurnal, 97 (11): 1377-1396. (In Russian).

Sofronova, V. E., Chepalov, V. A. and Petrov, K. A. (2007): Adaptive changes in the composition of photosynthetic pigments of pine needles Pinus sylvestris L. growing in cryolithozone. In: T. K. Golovko (eds.): Modern plant physiology: from molecules to ecosystems. VI Congress of plant physiologists of Russia. Part 3. Komi research center, Ural Division RAS, Syktyvkar, Russia, pp. 102-103. (In Russian).

TIESZEN, L. L., JOHNSON, P. L. (1968): Pigment structure of some arctic tundra communities. Ecology, 49 (2): 370-373. 
Tikнomirov, B. A. (1952): The importance of moss cover in the life of plants of the Far North. Botanicheskii Zhurnal, 37 (5): 629-638. (In Russian).

TUZHILKINA, V. V. (2009): Response of the pigment system of conifers to long-term industrial air pollution. Russian Journal of Ecology, 40(4): 227-232.

TuZhilkina, V. V., Veretennikov, A. V. (1981): The content of pigment pine and spruce. In: Ecological and biological bases of increasing productivity of taiga forests of the European North. Nauka, Leningrad, Russia, pp. 108-119. (In Russian).

Yatsco, Ya. N., Dymova, O. V. and Golovko, T. K. (2009): Pigment complex of ever- and wintergreen plants in the middle taiga subzone of the European North-East. Botanicheskii Zhurnal, 94(12): 1812-1820. (In Russian).

ZYuZIN, Yu. L. (2006): Stern face of the Khibiny. Advertising polygraphy, Murmansk, Russia, 236 p. (In Russian). 